\title{
Arc SWAT Model Integrated with Arc GIS - Based Evaluation of Land Use /Land Cover Change on the Hydrological Response of Muga Watershed, Abbay Basin, Ethiopia
}

\author{
Natnael Yasab Assefa (Master of Science in Hydraulic Engineering) \\ Debre Markos Institute of Technology \\ School of civil and water resources engineering \\ Academic program of Hydraulic and Water Resources Engineering \\ Debre Markos University, DebreMarkos, Ethiopia
}

\begin{abstract}
The study has shown the integration of Arc SWAT with Arc GIS and remote sensing tool are helpful analyze and evaluate both spatial and temporal land use/cover dynamics. It has also shown that Arc SWAT is an effective tool in analyzing the impacts of land use/cover changes on stream flow in areas with limited readily available data. This study is mainly focusing on the investigation of the impacts of land use / land cover changes on the stream flow of Muga watershed which is located in the East Choke Mountains watersheds, Upper Abbay Basin, East Gojjam Zone, Amhara Regional state, Ethiopia. Soil and Water Assessment Tool (SWAT) model were used it investigate the impact of land cover change on the stream flow. For this study SWAT Simulation is used in identifying the most vulnerable sub basins to the stream flow and sediment load changes of Muga watershed. The model was calibrated and validated using historic Stream flow data. The model was calibrated using stream flow data from 1993 to1998, validated from 1999 to2002. The $\mathrm{R}^{2}$ and NSE values were used to examine model performance and the result indicates 0.81 and 0.87 to $\mathrm{R}^{2}$ and 0.80 and 0.86 to NSE during calibration and validation respectively. The result of this analysis indicated that the mean monthly stream flow for wet months had increased by $17.75 \mathrm{~m}^{3} / \mathrm{s}$ while the dry season decreased by $12.76 \mathrm{~m}^{3} / \mathrm{s}$ during the $1995-2013$ period due to the land use and land cover change. The highest annual surface runoff was attributed by sub basin 5 whereas sub basin 6 contributes the highest ground water respectively for 1995, 2003 and 2013 land cover maps. In terms of sediment yield, sub basin 1 contributes a maximum load for the study periods.
\end{abstract}

Keywords: Arc SWAT, Arc GIS, Land Use /land cover change, Muga Watershed

DOI: $10.7176 / \mathrm{CER} / 13-2-01$

Publication date: April $30^{\text {th }} 2021$

\section{INTRODUCTION}

Land use/land cover (LU/LC) plays a vital role in water transport in the hydrologic cycle and primarily aids in reducing overland flows. Due to its effect on evaporation, transpiration and solar radiation interception, LU/LC is a driving factor in the energy balance within the hydrologic cycle (Aggarwal, 2009). The hydrology of local watersheds can vary drastically and water quality as well as water flow patterns is often dependent on a combination of soil, LU/LC and elevation characteristics unique to the area. For example, as forested area is lost and developed land expands it has shown to reduce base flow and/or an increase in soil erosion generally occurs (Walsh, 2005).

To study sustainable water resources and land use planning and development understanding the consequences of changes in land use and land cover scenarios is required. Human activities can affect the integrity of natural resources and the output of goods and services in the ecosystem. The development of new patterns of land use and land cover conditions can be enhanced by careful planning for the wellbeing of people (Arnold et al, 1998). The scientific framework for the analysis of land use systems have changed by the modelling tools which can addresses both spatial and temporal dynamics. It is a universal concern the changes in land use and land cover in river basins resulted in flooding events that has increased sediment loads (Gassman et al, 2007). There are some proportional alterations in the basin condition and hydrological response as a result of changes in land cover and land use scenarios. This is appropriately becoming one of the main existing land management issues

The response of hydrological processes of river basins influenced by human activities and climate changes have been widely studied (Kulkarni et al, 2014). In recent years, understanding the occurrences of natural processes at the watershed scale by the application of the model became an essential tool (Millennium Ecosystem Assessment, 2005). Geographic Information System (GIS) based spatial modeling has grown into an important tool to assess the effect of land use land cover changes on runoff and soil erosion studies and, consequently in advancement of suitable soil and water conservation strategies. Among several models SWAT linked with GIS has been extensively used in earlier studies.

Several research works have been carried out to study the impact of Land use /land cover change on the hydrology of river basins. Land use and land cover change very often due to the growing population and economy. 
In human history land, a fundamental factor of production, has been coupled to economic growth (Richards, 1909). The rapidly increasing population pressure in many rural areas of developing countries has often led to changes in land use in terms of deforestation, reclamation of wetlands, etc. mainly aiming at agricultural production. Neither population nor poverty alone constitute the sole and major underlying causes of land cover change world-wide (Lambin, 2001).

$\mathrm{LU} / \mathrm{LC}$ monitoring is an important aspect to determine the LU/LC change and likely impacts on the ecosystem (Eiumonh et al, 1997) that often lead to several environmental impacts, such as soil erosion, soil moisture, soil nutrients, change in micro-climate and so forth. These impacts not only affect within the watershed boundary but also bring in several harmful effects downstream (Eiumonh et al, 1997). Knowledge of LU/LC change is important for many planning and management activities. Technological, institutional and natural resource policy forces also play an important role in changing land use pattern (Rao, 2001). Therefore, knowledge of changes in LU/LC is becoming more important from both ecological and economical point of view (Lucas and Molenaar, 1990).

SWAT is a basin-scale continuous-time model that operates on a daily time step and is designed to predict the impact of management on water, sediment and agricultural chemical yields in ungauged watersheds. SWAT could accurately predict the relative impacts of hypothetical land use change in the $8.2 \mathrm{~km}^{2}$ experimental sub watershed within the San Pedro watershed (Hernandez et al, 2000). Simulated stream flow impacts with SWAT in response to historical land use shifts in the $3,150 \mathrm{~km}^{2}$ San Pedro watershed in southern Arizona and the Canyonville watershed in south central New York (Miller et al, 2002).

\section{METHODOLOGY}

\subsection{Description of Study Area}

The Muga watershed is located in the East Choke Mountains watersheds, Upper Blue Nile Basin, near Debre markos town in East Gojjam Zone, Amhara Regional state, Ethiopia. The watershed has an area of 73,815.25ha. In terms of administrative boundaries, it covers the three Woredas of East Gojjam zone (Debey Tilatgin, Enemay and Dejen).

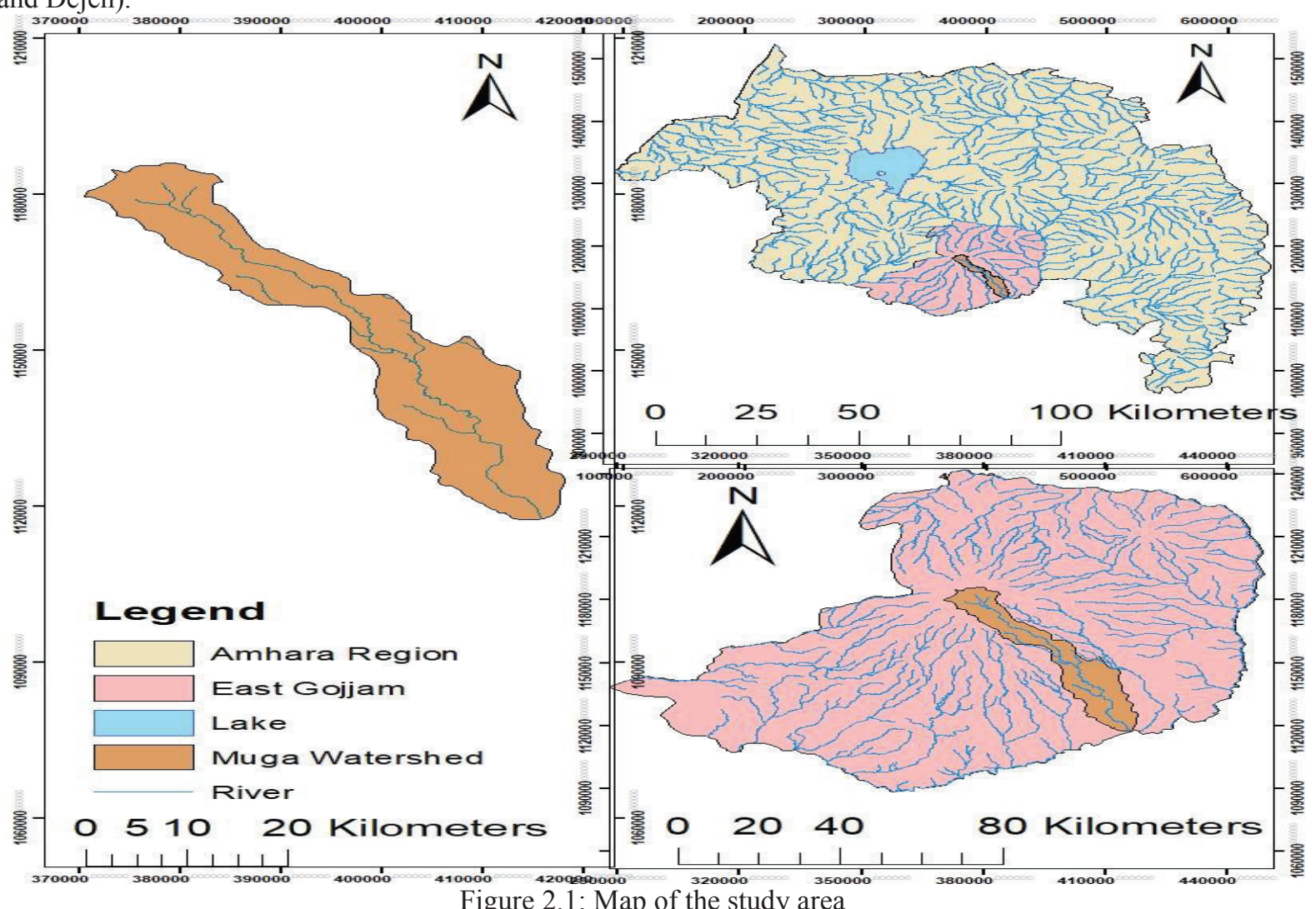

The agriculture production system in the study area is a subsistence type of crop production system. A major type of crops grown in the area includes: barely, wheat, maize, Teff, sorghum, and small extent oil crops. In this watershed, some farmers also practice traditional irrigation development activities from Perennial River and springs. Moreover, recently Kulkual-Arajo (is installed to irrigate 163ha, but irrigated only 52 ha) and Wodebeyesus (is installed to irrigate $270 \mathrm{ha}$, but it irrigate only $110 \mathrm{ha}$ ), generally, small and medium scale irrigation development project with a command area of 433ha is under operation in the watershed (but only 162 ha are irrigated). 


\subsection{Input data for SWAT Model}

SWAT is highly data intensive model that requires specific information about the watershed such as topography, land use and land cover, soil properties, weather data, and other land management practices. These data were collected from different sources and databases. Topography is defined by a digital elevation model (DEM), which describes the elevation of any point in a given area at a specific spatial resolution as digital file. The digital elevation model is one of the essential inputs required by SWAT to delineate the watershed to a number of subwatersheds. Digital Elevation Model (DEM) data are required to calculate the flow accumulation, stream networks, slope, stream length, and width of the channel within the watershed. For this study, Digital Elevation Model were collected from the Ministry of Water Resources, Irrigation and Electricity of Ethiopia with a spatial resolution of $30 \mathrm{~m}$. Meteorological data is needed by the SWAT model to simulate the hydrological conditions of the catchment.

The meteorological data required for this study were collected from the Ethiopian National Meteorological Services (NMS). The meteorological data collected were precipitation, maximum and minimum temperature, relative humidity, and wind speed and sunshine hours. The weather input data required for SWAT simulation includes daily data of precipitation, maximum and minimum temperature, relative humidity, wind speed and solar radiation. The weather data used were represented from four stations in and around Muga watershed, such as Debre markos, Dejen, Motta and Yetnora stations as shown in figure 2.2.

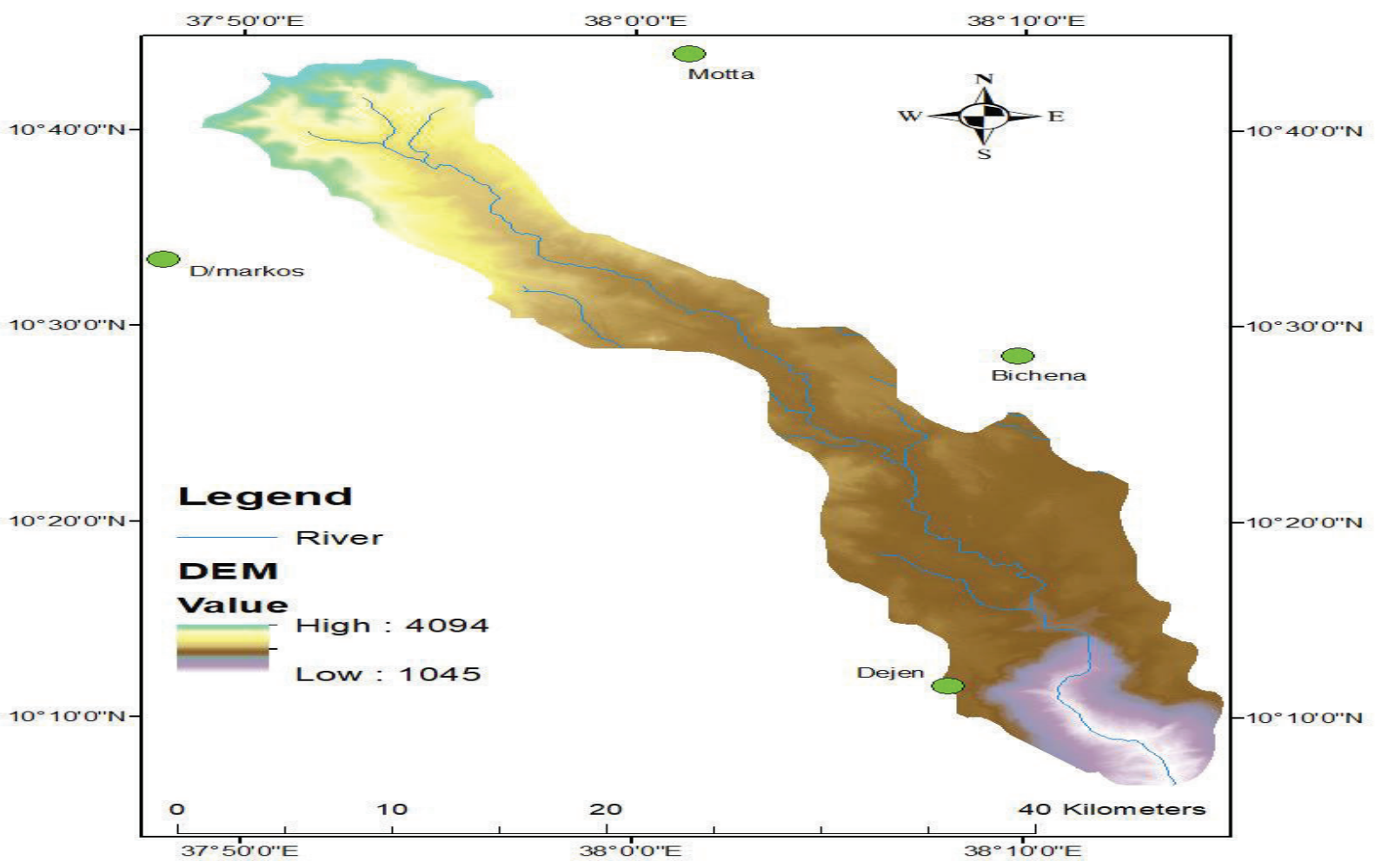

Figure 2.2: Location of meteorological stations in and around the watershed.

Table 2.1: Meteorological station names, locations and variables

\begin{tabular}{|l|l|l|l|l|l|l|l|l|l|}
\hline No & $\begin{array}{l}\text { Station } \\
\text { Name }\end{array}$ & $\begin{array}{l}\text { Latitude } \\
(\mathrm{deg})\end{array}$ & $\begin{array}{l}\text { Longitude } \\
(\mathrm{deg})\end{array}$ & $\begin{array}{l}\text { Rain } \\
\text { Fall }\end{array}$ & $\begin{array}{l}\text { Max } \\
\text { Temp }\end{array}$ & $\begin{array}{l}\text { Min } \\
\text { Tem }\end{array}$ & $\begin{array}{l}\text { Relative } \\
\text { humidity }\end{array}$ & $\begin{array}{l}\text { Wind } \\
\text { speed }\end{array}$ & $\begin{array}{l}\text { Sunshine } \\
\text { Hours }\end{array}$ \\
\hline 1 & $\begin{array}{l}\text { Debre } \\
\text { markos }\end{array}$ & 37.45 & 10.20 & $\sqrt{ }$ & $\sqrt{ }$ & $\sqrt{ }$ & $\sqrt{ }$ & $\sqrt{ }$ & $\sqrt{ }$ \\
\hline 2 & Dejen & 38.8 & 10.10 & $\sqrt{ }$ & $\sqrt{ }$ & $\sqrt{ }$ & & & \\
\hline 3 & Motta & 38.8 & 11.5 & $\sqrt{ }$ & $\sqrt{ }$ & $\sqrt{ }$ & & & \\
\hline 4 & Bichena & 37.01 & 10.10 & $\sqrt{ }$ & $\sqrt{ }$ & $\sqrt{ }$ & & & \\
\hline
\end{tabular}

Soil data is one of the major input data for the SWAT model with inclusive and chemical properties. The soil map of the study area was also obtained from Ministry of Water Resources, irrigation and electricity of Ethiopia. SWAT model requires soil physical and chemical properties such as soil texture, available water content, hydraulic conductivity, bulk density and organic carbon content for different layers of each soil type.

Land Use is one of the highly influencing the hydrological properties of the watersheds. It is one of the main input data of the SWAT model to describe the Hydrological Response Units (HRUs) of the watersheds. The land use map of the study area was also obtained from Ethiopian mapping agency. The stream flow data of the Muga watershed is needed for the calibration and validation of the model. The average monthly stream flow data (1990- 
2002) is quite sufficient and were collected from the Minister of Water Resources, irrigation and electricity of Ethiopia for the Muga watershed.

\subsection{Description of Hydrological Model}

Soil and Water Assessment Tool is a physically-based and semi-distributed river basin scale model developed to quantify the impact of land management practices on water, sediment and agricultural chemical yields in large complex watersheds with varying soils, land use and management conditions over long periods of time. The main components of SWAT include weather, surface runoff, return flow, percolation, evapotranspiration, transmission losses, pond \& reservoir storage, crop growth \& irrigation, groundwater flow, reach routing, nutrient \& pesticide loading, and water transfer.

In Arc SWAT, the watershed is delineated into a number of sub-basins, which are further divided into Hydrological Response Units (HRUs) that consist of homogeneous land use, management, and soil characteristics. The HRUs represent percentages of the sub-watershed area and are not identified spatially within a simulation. Subdividing the watershed into HRUs enables the model to reflect differences in evapotranspiration and other hydrologic conditions for different land covers and soils. Runoff is predicted separately for each HRU and routed to obtain the total runoff for the watershed which increases the accuracy of load predictions. By delineating the watershed, the user is able to reference different areas of the watershed to one another spatially. For each sub-basin input, information is grouped into the following categories: climate; groundwater; HRUs; ponds/wetlands; and the main channel draining the sub-basin.

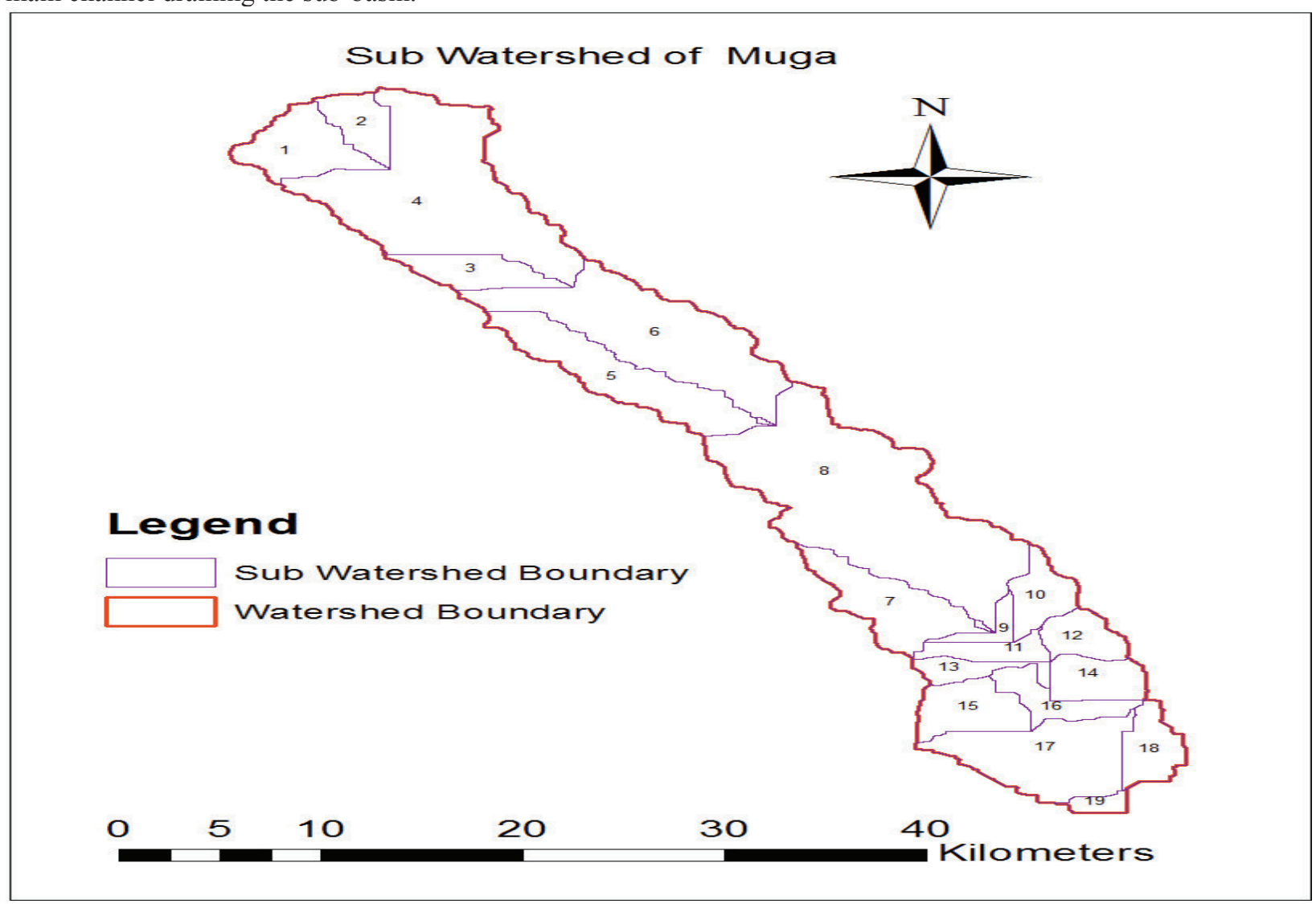

Figure 2.2: Sub watersheds map of the Muga watershed

Water balance is the driving force behind everything that happens in the watershed. As simulated by the model, the hydrologic cycle must conform to what is happening in the watershed to accurately predict movement of sediments (Nie et al, 2011). The hydrology is simulated in two major ways: (1) the Land Phase, which controls sediment, nutrient and pesticides loading to each channel from sub-basins, and (2) the Water or Routing Phase that controls the movement through the channel network to the watershed outlet. The SWAT soil-water routing feature is calculated from the interaction of four main pathways: soil evaporation, plant uptake and transpiration, lateral flow and percolation. Sediment yield in SWAT is estimated with the modified soil loss equation (MUSLE) developed by (Williams and Berndt, 1977). The hydrologic cycle is simulated by SWAT based on the following water balance equation. 


$$
\begin{array}{r}
S W_{t}=S W_{o}+\sum\left(R_{\text {day }}-Q_{\text {surf }}-E_{a}-W_{\text {sweep }}\right. \\
\left.-Q_{g w}\right) \ldots \ldots \ldots \ldots \ldots \ldots \ldots \ldots \ldots \ldots
\end{array}
$$

Where : $\mathrm{t}$ is the time in days, $\mathrm{SW}_{\mathrm{t}}$ is the soil water content at time $\mathrm{t}(\mathrm{mm}), \mathrm{SW}_{0}$ is the initial soil water content $(\mathrm{mm}), \mathrm{R}_{\text {day }}$ is amount of precipitation on day $(\mathrm{mm}), \mathrm{Q}_{\text {surf }}$ the amount of surface runoff on day $(\mathrm{mm}), \mathrm{E}_{\mathrm{a}}$ is the amount of evapotranspiration on day $(\mathrm{mm}), \mathrm{W}_{\text {sweep }}$ is the amount of water entering the vadose zone from the soil profile on day $(\mathrm{mm}), \mathrm{Q}_{\mathrm{gw}}$ is the amount of return flow on day $(\mathrm{mm})$.

SWAT was chosen for the compatibility of available data and software and for its complex representation of fine spatial scales. Moreover, SWAT has become popular among environmental managers since it has been adopted as a component of the US Environmental Protection Agency's Better Assessment Science Integrating Point and Non-Point Sources (BASINS) software packages. SWAT has shown to be successful for land-use change assessments and has generated an expanding body of research projects. SWAT has also been extensively validated across the US for stream-flow and sediment loads.

SWAT provides two infiltration methods for estimating the surface runoff volume component from HRUs, namely, the SCS-curve number (CN) method [SCS, 1972] or the Green \&Ampt infiltration method (Green WH and Ampt G., 1911). Whereas the CN-method uses daily rainfall rates, the Green \&Ampt technique requires smaller time-steps to properly simulate the infiltration process. This discards the use of the latter method in the present study. Here the surface runoff is modeled in SWAT using the SCS curve number method, i.e.

$Q_{\text {surf }}$

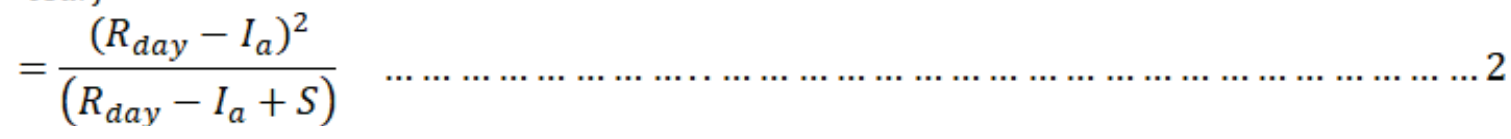

Where: $Q_{\text {surf }}$, accumulated runoff or rainfall excess $\left(\mathrm{mm} \mathrm{H}_{2} 0\right)$, Rday, rainfall depth for the day $\left(\mathrm{mm}_{2} 0\right)$, $\mathrm{I}_{\mathrm{a}}$, initial abstractions which includes surface storage, interception and infiltration, prior to runoff $\left(\mathrm{mm} \mathrm{H}_{2} 0\right)$, and which is usually taken as equal $0.2 \mathrm{~S}$, with $\mathrm{S}$, retention parameter $\left(\mathrm{mm} \mathrm{H}_{2} 0\right)$. The retention parameter $\mathrm{S}$ is defined by: $S$

$$
\begin{aligned}
& =25.4\left\lceil\frac{1000}{C N}\right.
\end{aligned}
$$

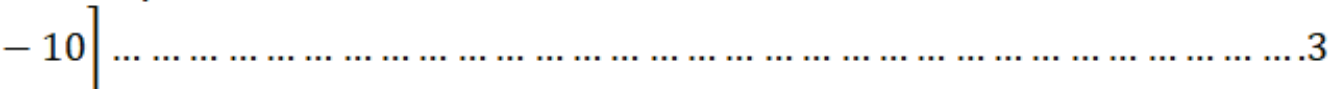

Where $\mathrm{CN}$ is the SCS-curve number, which ranges from 0 to 100 , depending on the soil permeability, land use and the antecedent soil water conditions. There are numerous other parameters in SWAT which control the various hydrological processes acting a across a basin, namely, the transitions and routing of the flow components across the different compartments of the SWAT-simulated section of the hydrological cycle. 


\section{RESULTS AND DISCUSSION}

\subsection{Land Use / Land Cover Maps}
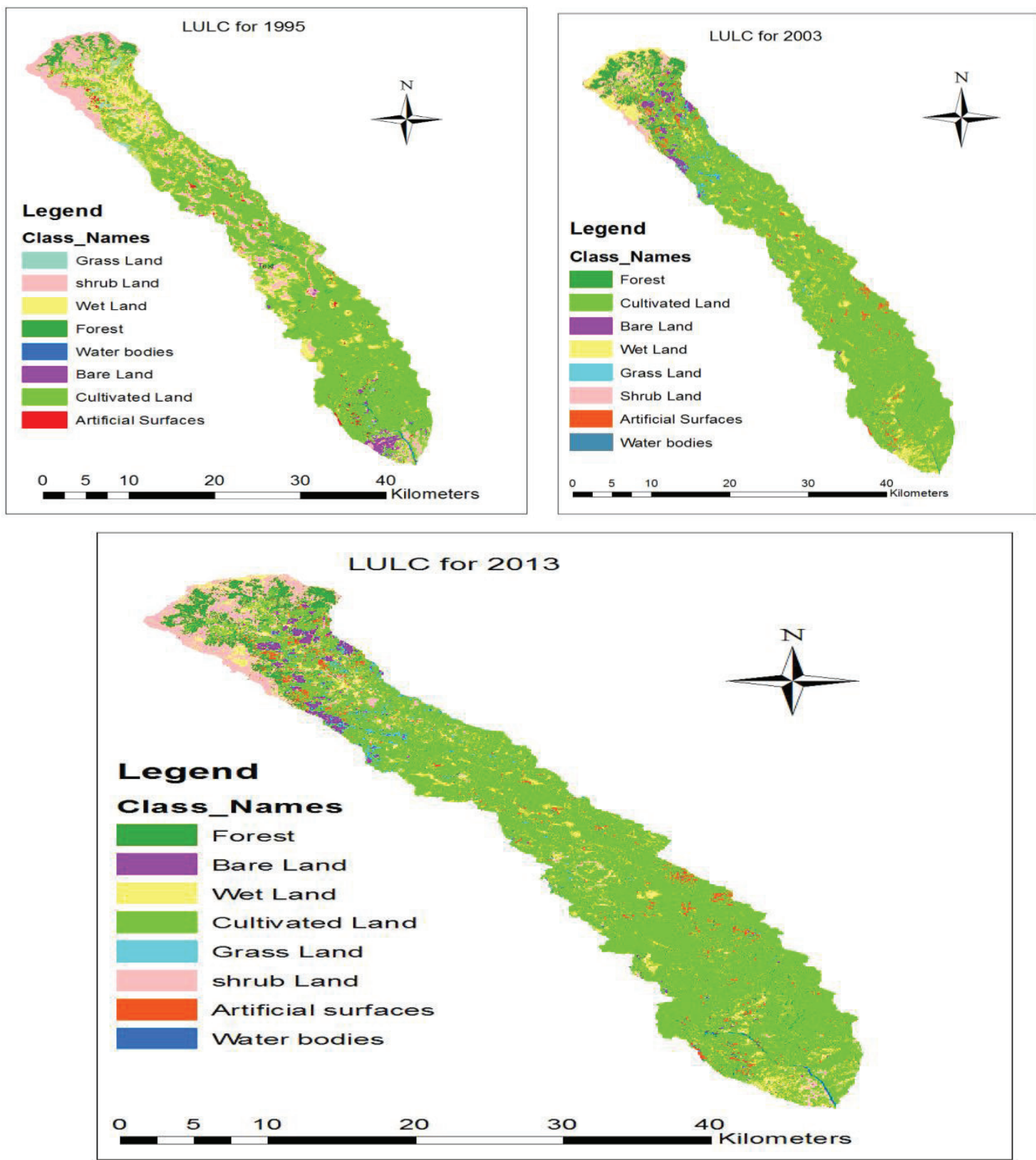

Figure 3.1: Map of the Land use types of Muga watershed

The land use / land cover map of 1995 in the figure 3.1 shows that the total cultivated land coverage class was about $21 \%$ of the total area of the watershed. It increased rapidly and became $55 \%$ of the watershed in 2003 and $72 \%$ of the watershed in 2013 . This is mainly because of the population growth that caused the increase in demand for new cultivation land and settlement which in turn resulted shrinking on other types of land use and land cover of the area. On the land use / land cover map of the year 1995 in the figure 3.1 shows the total forest coverage was about $6 \%$ of the total area of the watershed. On the land use and land cover map of the year 2003 it reduced to almost $5 \%$ of the total area and it reduced to almost $4 \%$ of the total area. These deforestation activities that have mostly takes place for the purpose of agriculture. In general, during the 18 years period the cultivated land increased almost $51 \%$ whereas the forest land decreased $2 \%$. The individual class areas and change statistics for the two periods are summarized in table 3.1 . 
Table 3.1: Area of land covers types and change statistics of Muga watershed for the period of $1995-2013$.

\begin{tabular}{|l|l|l|l|l|l|l|l|l|}
\hline \multirow{2}{*}{ Land cover types } & 1995 & 2003 & 2013 & $2013-1995$ & \\
\cline { 2 - 10 } & $\mathrm{Ha}$ & $\%$ & $\mathrm{Ha}$ & $\%$ & $\mathrm{Ha}$ & $\%$ & Ha & $\%$ \\
\hline Cultivated land & 15227.3619 & 21.23 & 39571.0577 & 55.17 & 51651.9000 & 72.01 & 36422.3003 & 50.78 \\
\hline Forest & 4375.2665 & 6.1 & 3514.5583 & 4.9 & 2840.2200 & 3.96 & -1534.9296 & -2.14 \\
\hline Shrub land & 10170.701 & 14.18 & 6053.6474 & 8.44 & 560.7900 & 0.78 & -9611.2411 & -13.4 \\
\hline Grass land & 44391.023 & 61.89 & 19946.9116 & 27.81 & 16905.449 & 16.3 & -15485.574 & -21.6 \\
\hline Artificial surfaces & 5.7381 & 0.87 & 652.703688 & 0.91 & 687.3100 & 0.96 & 37.2974 & 0.52 \\
\hline Bare land & 6168.40848 & 8.6 & 2632.33246 & 3.67 & 68.8500 & 0.10 & -6096.683 & -8.5 \\
\hline Water body & 57.3805 & 0.08 & 25.5177 & 0.03 & 7.17257 & 0.01 & -24.8628 & -0.04 \\
\hline Wet land & 208.004 & 0.29 & 71.7257 & 0.1 & 7.17257 & 0.01 & -134.2783 & -0.19 \\
\hline
\end{tabular}

\subsection{Sensitivity Analysis}

Sensitivity analysis was performed on flow parameters of SWAT on monthly time steps with observed data of the Muga River gauge station. For this analysis, 26 parameters were considered and only 10 parameters were identified to have significant influence in controlling the stream flow in the watershed.

The result of the sensitivity analysis indicated that these 10 flow parameters are sensitive to the SWAT model i.e the hydrological process of the study watershed mainly depends on the action of these parameters. Curve number $\left(\mathrm{CN}_{2}\right)$, ground water delay (GW_DELAY), soil available water capacity (SOL_AWC), soil evapotranspiration factor (ESCO), and Effective hydraulic conductivity of the main channel (CH_K2) are identified to be highly sensitive parameters and retained rank 1 to 5 , respectively.

The other parameters such as, total soil depth (SOL_Z), Manning's roughness coefficient (CH_N2) Alpha factor (ALPHA_BF), threshold depth of water in the shallow aquifer required for return flow (GWQMN) and surface lag (SURLAG) are identified as slightly important parameters that were retained rank 6 to 10, respectively. The remaining parameters (16 parameters) were not considered during calibration process as the model simulation result was not sensitive to these parameters in the watershed. These parameters are related to ground water, runoff and soil process and thus influence the stream flow in the watershed. The result of the analysis was found that Curve number $\left(\mathrm{CN}_{2}\right)$ is the most important factor influencing stream flow in the Muga watershed. The Curve number $\left(\mathrm{CN}_{2}\right)$ is a direct index of surface runoff response to changes in stream flow. The Muga watershed is characterized with tertiary basalt and volcanic regional geology that have good potential for ground water recharge. The other most influencing stream flow parameter in this analysis is the ground water delay (GW_DELAY).

\subsection{Auto- calibration Analysis}

Calibration was done for sensitive flow parameters of SWAT with observed average monthly stream flow data. In this procedure, the values of the parameters were varied iteratively within the allowable ranges until the simulated flow as close as possible to observed stream flow. Then, auto calibration was run using sensitive parameters that were identified during sensitivity analysis.

Table 3.2: flow sensitive parameters and their fitted value in SUFI_2

\begin{tabular}{|l|l|l|l|}
\hline \multicolumn{2}{|c|}{ Parameters } & \multirow{2}{*}{ Lower and upper bound } & Fitted value \\
\hline Name & SCS runoff curve number $(\%)$ & -0.2 to 0.4 & 0.09 \\
\hline GW_DELAY & Ground water delay (days) & 46.4 to 458.12 & 447.41 \\
\hline SOL_AWC & Soil available water capacity (water/mm soil) & -0.35 to 0.48 & 0.05 \\
\hline ESCO & Soil evaporation compensation factor & 0.03 to 1.83 & 1.73 \\
\hline CH_K2 & $\begin{array}{l}\text { Effective hydraulic conductivity of the main } \\
\text { Channel (mm/hr.) }\end{array}$ & -11.35 to 113.25 & 52.2 \\
\hline SOL_Z & Total soil depth (mm) & -0.2 to 0.2 & -0.18 \\
\hline CH_N2 & Manning's roughness coefficient & -0.12 to 0.14 & -0.1 \\
\hline ALPHA_BF & Base flow alpha factor (days) & 0.44 to 1.52 & 0.61 \\
\hline GWQMN & $\begin{array}{l}\text { Threshold depth of water in the shallow aquifer } \\
\text { required for return flow (mm) }\end{array}$ & 0.08 to 2.56 & 1.97 \\
\hline SURLAG & Surface lag & 0.04 to 1.06 & 0.96 \\
\hline
\end{tabular}


FLOW_OUT_19

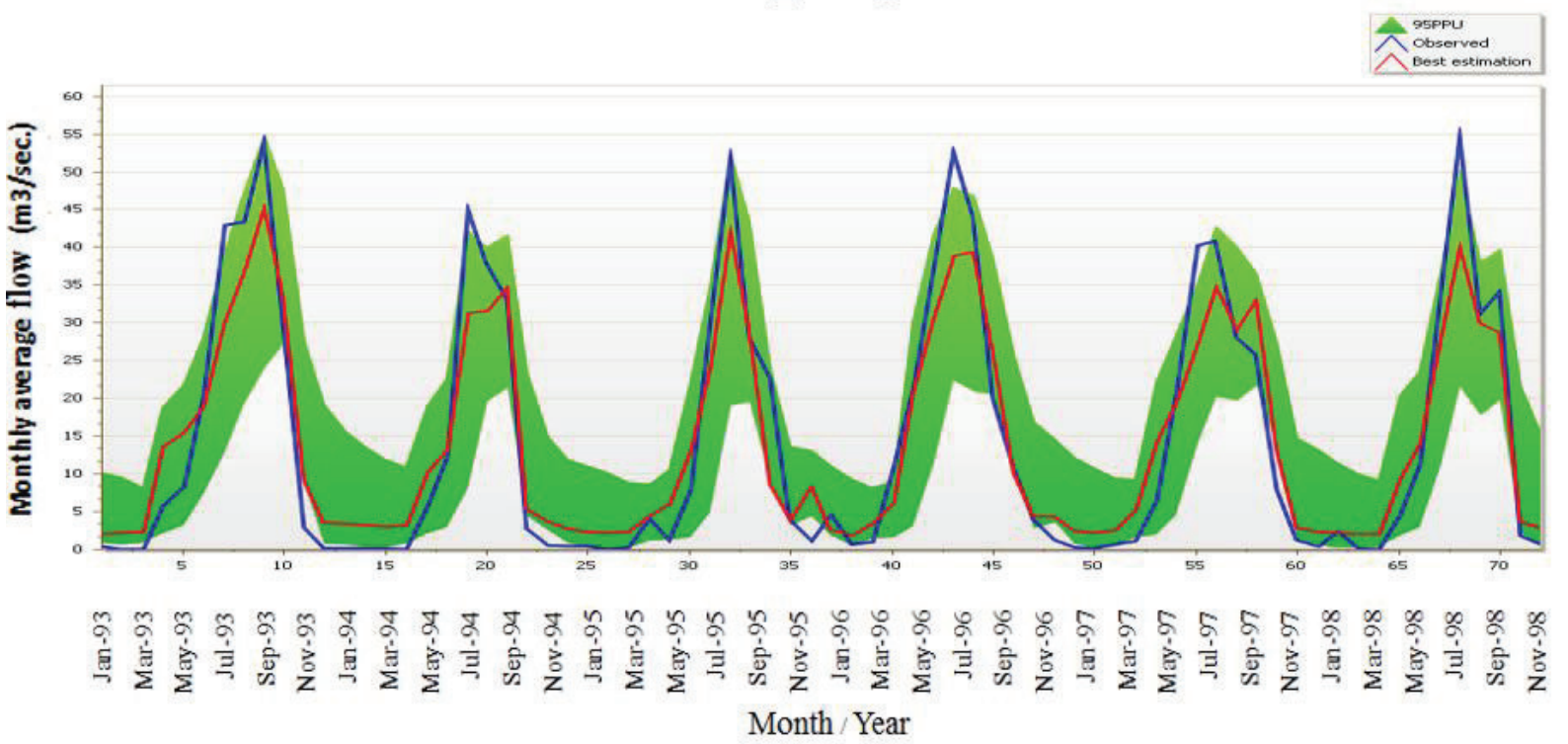

Figure 3.2: The result of calibration for average monthly stream flows.

\subsection{Model Validation and Evaluation}

The model validation was also performed for 4 years from 1999 to 2002 without further adjustment of the calibrated parameters. The validation result for monthly flow is shown in the figure 3.3. The validation simulation also showed a good agreement between the simulated and measured monthly flow with the ENS value of 0.89 and $\mathrm{R}^{2}$ of 0.90 as shown in Table 3.3 .

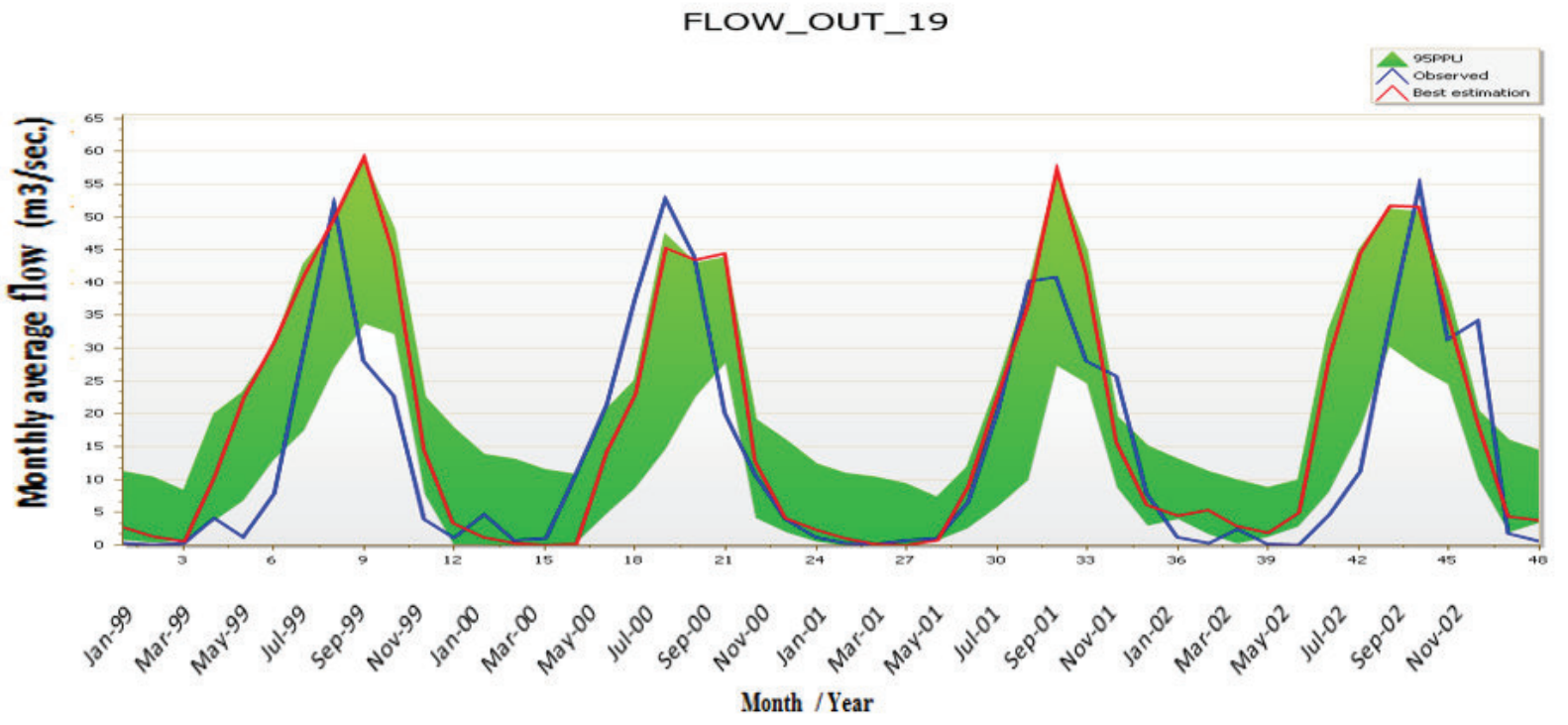

Figure 3.3: The result of Validation for average monthly stream flows.

The measured and simulated average monthly flow for Muga was obtained, during the calibration period; they were 18.334 and $16.780 \mathrm{~m}^{3} / \mathrm{s}$, respectively. The measured and simulated average monthly flow for the validation period was 14.714 and $17.814 \mathrm{~m}^{3} / \mathrm{s}$, respectively. These indicate that there is a reasonable agreement between the measured and the simulated values in both calibration and validation periods (Table 3.4).

Table 3.4 : Comparison of Measured and simulated monthly flow for calibration and validation simulations

\begin{tabular}{|l|l|l|c|c|}
\hline \multirow{2}{*}{ Period } & Average monthly flow $\left(\mathrm{m}^{3} / \mathrm{s}\right)$ & \multirow{2}{*}{ ENS } & $\mathrm{R}^{2}$ \\
\cline { 2 - 3 } & Measured & Simulated & 0.86 & 0.88 \\
\hline Calibration (1993-1998) Period & 18.334 & 16.780 & 0.89 & 0.90 \\
\hline Validation (1999-2002) Period & 14.714 & 17.814 & 0 \\
\hline
\end{tabular}

As indicated in the Table 3 , the model performance values for calibration and validation of the flow simulations are adequately satisfactory. This indicates that the physically processes involved in the generation of 
stream flows in the watershed were adequately captured by the model. Hence, the model simulations can be used for various water resource management and development aspects.

\subsection{Impact of Lu/Lc by Using SWAT Model}

Hydrological effects of specific land use changes in a catchment of the river Muga in East Gojjam (Muga watershed, $738.15 .25 \mathrm{~km}^{2}$ ), Ethiopia, through the application of the SWAT model on a monthly time step. It should be noted that although the model was run for 26-years (1990 to 2015), the first 5 years of simulated output were is regarded in the calibration process, since they are required by the model as a warm-up period. This period was essential for the stabilization of parameters, as the results sometimes vary significantly from the observed values. The authors investigated the effect of land use change by using three land use scenarios which are: expansion of agricultural land, complete deforestation and expansion of urban area in the Muga sub-basin. All the three scenarios resulted in an increased in stream flow during wet season and decreased during the dry season. Thus, the final calibration period was from April 1995 to December 2010. The result can be quite satisfactory.

The hydrologic model SWAT (Soil and Water Assessment Tool) was used to assess impacts on runoff and evapotranspiration. Two model runs were performed and compared using the land use classifications of 1989/1990 and 2009/2010.

\subsection{Effects of LULCC on stream flow and simulated sediment load of the Study area}

After calibrating and validating of the model using the Three land use and land cover data for their respective periods of 1993 to 1998 and 1999 to 2002 respectively, SWAT was run using the three land cover data (1995, 2003 and 2013) for the period of 1993. This process gave the discharge outputs for all land use and land cover patterns. Then, these outputs were compared and the discharge change during the wettest months of stream flow taken as June, July and August and driest stream flow are considered in the months of January, February and March were calculated and used as indicators to estimate the effect of land use and land cover change on the stream flow.

Table 3.5 presents the mean monthly wet and dry month's stream flow for 1995, 2003 and 2013 land use and land cover maps and its variability (1995 -2013).

\begin{tabular}{|c|c|c|c|c|c|c|c|}
\hline \multirow{2}{*}{\multicolumn{2}{|c|}{ LULC data of 1995}} & \multirow{2}{*}{\multicolumn{2}{|c|}{ LULC data of 2003}} & \multirow{2}{*}{\multicolumn{2}{|c|}{ LULC data of 2013}} & \multirow{2}{*}{\multicolumn{2}{|c|}{$\begin{array}{l}\text { Mean monthly } \\
\text { flow change }\end{array}$}} \\
\hline & & & & & & & \\
\hline $\begin{array}{l}\text { Wet } \\
\text { months } \\
\text { (Jun, Jul, } \\
\text { Aug) }\end{array}$ & $\begin{array}{l}\text { Dry } \\
\text { months } \\
\text { (Jan, Feb, } \\
\text { Mar) }\end{array}$ & $\begin{array}{l}\text { Wet months } \\
\text { (Jun, Jul, } \\
\text { Aug) }\end{array}$ & $\begin{array}{l}\text { Dry months } \\
\text { (Jan, Feb, } \\
\text { Mar) }\end{array}$ & $\begin{array}{l}\text { Wet months } \\
\text { (Jun, Jul, } \\
\text { Aug) }\end{array}$ & $\begin{array}{l}\text { Dry months } \\
\text { (Jan, Feb, Mar) }\end{array}$ & Wet & Dry \\
\hline 35 & 15.71 & 42.31 & 10.21 & 52.75 & 2.95 & +17.75 & -12.76 \\
\hline
\end{tabular}

The mean monthly stream flow for wet months had increased by $17.75 \mathrm{~m}^{3} / \mathrm{s}$ while the dry season decreased by $12.76 \mathrm{~m}^{3} / \mathrm{s}$ during the $1995-2013$ period due to the land use and land cover change.

To assess the change in the contribution of the components of the stream flow due to the land use and land cover change and the simulated sediment yield, analysis was made on the surface runoff (SURQ) and groundwater flow (GWQ). Table 3.5 presents the SURQ and GWQ of the stream simulated using 1993 and 2002 land use and land cover map for the same period.

Table 3.6: Annual average Surface runoff, Ground water flow and sediment load of the stream simulated using 1995, 2003 and 2013 LULC map

\begin{tabular}{|l|l|l|l|}
\hline Item & LULC 1995 & LULC 2003 & LULC 2013 \\
\hline Surface Runoff,mm & 309.37 & 316.21 & 329.37 \\
\hline Groundwater (Deep Aq), mm & 25.32 & 20.24 & 17.24 \\
\hline Groundwater (Shal Aq), mm & 380.21 & 348.41 & 345.14 \\
\hline Total Aq Recharge mm & 414.71 & 399.31 & 379.01 \\
\hline Total Water Yld, mm & 736.21 & 716.64 & 707.36 \\
\hline total sediment loading, t/ha & 11.124 & 27.431 & 43.515 \\
\hline
\end{tabular}

As the table 3.6 showed as the SURQ and GWQ components of the stream simulated using the 1995 land use and land cover map for the period of 1993 to 2002 were $309.37 \mathrm{~mm}$ and $380.21 \mathrm{~mm}$, using 2003 land use and land cover map were $316.21 \mathrm{~mm}$ and $348.41 \mathrm{~mm}$ while using 2013 land use and land cover map were $329.37 \mathrm{~mm}$ and 345.14 , respectively. The contribution of surface runoff has increased from $309.37 \mathrm{~mm}$ to $329.37 \mathrm{~mm}$ whereas the ground water flow has decreased from $380.21 \mathrm{~mm}$ to $345.14 \mathrm{~mm}$ due to the land use and land cover change occurred between the periods of 1990 to 2015. This is because of the expansion of agricultural land over forest that results in the increase of surface runoff following rainfall events. Researcher can explain this in terms of the crop soil moisture demands.

Crops need less soil moisture than forests; therefore, the rainfall satisfies the soil moisture deficit in agricultural lands more quickly than in forests there by generating more surface runoff where the area under 
agricultural land is extensive. And this causes variation in soil moisture and groundwater storage. This expansion also results in the reduction of water infiltrating in to the ground. Therefore, discharge during dry months (which mostly comes from base flow) decreases, whereas the discharge during the wet months increases. These results demonstrate that the land use and land cover change have a significant effect on infiltration rates, on the runoff production, and on the water retention capacity of the soil.

Sediment yield has increased from 1995 to 2003 and from 2003 to 2013. As a result of continuous agricultural land increment, sediment loadings of the area are increasing contributing maximum sediment rate. The study also revealed that, the expansion of farm land has attributed to the increased sediment load.

Different studies have been conducted in different parts of the country to evaluate the effects of land use and land cover changes on stream flow. A modelling study of Anger watershed, in Ethiopia, introduced that the surface runoff increased and the base flow decreased due to the expansion of agricultural land and declined of forest land. Study on a Hare watershed, in Southern Ethiopia, (Tadele, 2007) reported that due to the replacement of natural forest in to farmland and settlements, the mean monthly discharge for wet months had increased while in the dry season decreased. In the study of Chemoga watershed, in Blue Nile basin, (Abebe, 2005) reported that large volume of surface runoff occurs during the storm events since the area under forest cover decreased.

Generally, the hydrological investigation with respect to the land use and land cover change within Muga watershed showed that the flow characteristics have changed, with increase in surface flow and reduction of base flows through the selected period of study.

\subsection{Contribution of Sub Basins to the stream flow and simulated sediment yield}

Table 3.7: Maximum and minimum surface runoff, Groundwater, sediment load contributed by each sub basin for period of 1995

\begin{tabular}{|c|c|c|c|c|c|c|}
\hline \multirow[t]{3}{*}{ No. sub basin } & \multicolumn{6}{|c|}{ Surface runoff, Groundwater, sediment load contributed by each sub basin. } \\
\hline & \multicolumn{2}{|c|}{ Surface runoff, mm } & \multicolumn{2}{|c|}{ Groundwater, $\mathrm{mm}$} & \multicolumn{2}{|c|}{ Sediment yield, $\mathrm{t} / \mathrm{h}$} \\
\hline & Maximum & minimum & Maximum & Minimum & Maximum & Minimum \\
\hline 1 & 391.26 & 156.16 & 562.12 & 360.52 & 48.20 & 0.01 \\
\hline 2 & 358.15 & 147.45 & 420.01 & 244.86 & 0.52 & 0.001 \\
\hline 3 & 387.16 & 150.05 & 575.90 & 378.80 & 0.90 & 0.04 \\
\hline 4 & 382.59 & 150.26 & 581.49 & 360.23 & 8.15 & 0.01 \\
\hline 5 & 408.19 & 160.68 & 687.56 & 433.58 & 0.55 & 0.01 \\
\hline 6 & 390.93 & 155.81 & 690.58 & 370.95 & 1.39 & 0.01 \\
\hline 7 & 340.63 & 108.06 & 549.81 & 316.68 & 0.60 & 0.01 \\
\hline 8 & 340.59 & 113.44 & 549.42 & 316.28 & 0.70 & 0.01 \\
\hline 9 & 340.79 & 115.78 & 549.09 & 318.08 & 0.52 & 0.30 \\
\hline 10 & 340.64 & 110.55 & 549.95 & 310.83 & 0.62 & 0.02 \\
\hline 11 & 340.69 & 140.22 & 549.28 & 330.90 & 0.51 & 0.35 \\
\hline 12 & 341.64 & 115.98 & 549.97 & 380.71 & 0.31 & 0.30 \\
\hline 13 & 340.65 & 130.26 & 549.97 & 398.77 & 0.30 & 0.30 \\
\hline 14 & 340.59 & 134.16 & 549.59 & 398.56 & 0.33 & 0.30 \\
\hline 15 & 340.61 & 130.27 .27 & 545.51 & 257.79 & 0.60 & 0.36 \\
\hline 16 & 348.37 & 90.96 & 570.43 & 280.81 & 1.96 & 0.34 \\
\hline 17 & 330.14 & 130.48 & 510.97 & 280.01 & 0.76 & 0.01 \\
\hline 18 & 346.84 & 107.23 & 460.99 & 275.97 & 1.90 & 0.31 \\
\hline 19 & 327.19 & 110.04 & 495.61 & 285.58 & 2.09 & 0.01 \\
\hline
\end{tabular}


Table 8: Maximum and minimum surface runoff, Groundwater, sediment load contributed by each sub basin for period of 2003

\begin{tabular}{|c|c|c|c|c|c|c|}
\hline \multirow[t]{3}{*}{ No. sub basin } & \multicolumn{6}{|c|}{ Surface runoff, Groundwater, sediment load contributed by each sub basin. } \\
\hline & \multicolumn{2}{|c|}{ Surface runoff, $\mathrm{mm}$} & \multicolumn{2}{|c|}{ Groundwater, $\mathrm{mm}$} & \multicolumn{2}{|c|}{ Sediment yield, $\mathrm{t} / \mathrm{h}$} \\
\hline & Maximum & minimum & Maximum & Minimum & Maximum & Minimum \\
\hline 1 & 393.24 & 155.59 & 559.19 & 350.52 & 50.37 & 0.02 \\
\hline 2 & 353.25 & 152.45 & 413.01 & 235.86 & 0.51 & 0.01 \\
\hline 3 & 396.19 & 158.05 & 571.91 & 371.80 & 0.90 & 0.04 \\
\hline 4 & 395.59 & 157.26 & 580.49 & 362.23 & 10.15 & 0.01 \\
\hline 5 & 410.17 & 158.68 & 679.46 & 434.58 & 0.55 & 0.01 \\
\hline 6 & 395.97 & 159.81 & 686.59 & 377.95 & 1.49 & 0.01 \\
\hline 7 & 344.63 & 110.06 & 548.81 & 317.68 & 0.64 & 0.01 \\
\hline 8 & 345.59 & 117.44 & 548.42 & 318.28 & 0.74 & 0.01 \\
\hline 9 & 345.79 & 117.78 & 548.09 & 320.08 & 0.53 & 0.32 \\
\hline 10 & 345.64 & 117.55 & 546.95 & 318.83 & 0.62 & 0.02 \\
\hline 11 & 344.69 & 144.22 & 540.28 & 338.90 & 0.53 & 0.35 \\
\hline 12 & 345.64 & 129.98 & 550.97 & 388.71 & 0.33 & 0.38 \\
\hline 13 & 345.65 & 139.26 & 550.97 & 398.77 & 0.35 & 0.35 \\
\hline 14 & 344.59 & 144.16 & 550.59 & 398.56 & 0.39 & 0.39 \\
\hline 15 & 344.61 & 130.27 .27 & 540.51 & 255.79 & 0.85 & 0.36 \\
\hline 16 & 350.37 & 109.96 & 563.43 & 276.81 & 1.96 & 0.34 \\
\hline 17 & 330.14 & 132.48 & 509.87 & 278.01 & 0.76 & 0.01 \\
\hline 18 & 348.84 & 111.23 & 491.98 & 265.96 & 1.95 & 0.31 \\
\hline 19 & 330.17 & 111.04 & 489.61 & 285.58 & 2.09 & 0.01 \\
\hline
\end{tabular}

Table 9: Summary of surface run off, groundwater and sediment load contributed by the sub basins

\begin{tabular}{|c|c|c|c|c|c|}
\hline \multirow[t]{2}{*}{ Item } & \multicolumn{2}{|l|}{ Sub basins } & \multicolumn{2}{|c|}{ Average annual Surface runoff ,mm } & \multirow[b]{2}{*}{$\begin{array}{l}\text { Simul } \\
\text { ation } \\
\text { period }\end{array}$} \\
\hline & $\begin{array}{l}\text { Sub basin for } \\
\text { maximum }\end{array}$ & $\begin{array}{l}\text { Sub basin for } \\
\text { minimum }\end{array}$ & $\begin{array}{l}\text { Maximum } \quad\left(Q_{\text {surf }}>\right. \\
400 \mathrm{~mm})\end{array}$ & $\begin{array}{l}\text { Minimum } \\
\left(Q_{\text {surf }}<115\right)\end{array}$ & \\
\hline 1 & 5 and 6 & $7,10,16,18$ and 19 & $\begin{array}{l}408.19,410.17,414 . \\
15 \text { and } 400.93\end{array}$ & $\begin{array}{l}108.66,110.55,90.96,107 . \\
23,110,109.96,111.23,111 \\
.04,112.06,109.96 \\
\text { and114.23 }\end{array}$ & $\begin{array}{l}1995 \\
2003 \\
2013\end{array}$ \\
\hline \multirow[t]{2}{*}{ Item } & \multicolumn{2}{|l|}{ Sub basins } & \multicolumn{2}{|c|}{ Average annual Groundwater flow , mm } & \multirow[b]{2}{*}{$\begin{array}{l}\text { Simul } \\
\text { ation } \\
\text { period }\end{array}$} \\
\hline & $\begin{array}{l}\text { Sub basin for } \\
\text { maximum }\end{array}$ & $\begin{array}{l}\text { Sub basin for } \\
\text { minimum }\end{array}$ & $\begin{array}{l}\text { Maximum } \\
\left(\mathrm{Q}_{\mathrm{gw}}>600 \mathrm{~mm}\right)\end{array}$ & $\begin{array}{l}\text { Minimum } \\
\left(\mathrm{Q}_{\mathrm{gw}}<275\right)\end{array}$ & \\
\hline 2 & 5 , and 6 & $16,17,18$ and 19 & $\begin{array}{l}687.56,690.58,679 \\
46,686.59,681.46 \\
\text { and } 682.58\end{array}$ & $\begin{array}{l}280.81,280.01,275.97,288 \\
.59,276.91278 .01285 .5,27 \\
6.01 \text { and } 282.58\end{array}$ & $\begin{array}{l}1995 \\
2003 \\
2013\end{array}$ \\
\hline \multirow[t]{2}{*}{ Item } & \multicolumn{2}{|l|}{ Sub basins } & \multicolumn{2}{|c|}{ sediment loading ,t/ha } & Simul \\
\hline & $\begin{array}{l}\text { Sub basin for } \\
\text { maximum }\end{array}$ & $\begin{array}{l}\text { Sub basin for } \\
\text { minimum }\end{array}$ & $\operatorname{Maximum}(>1)$ & $\operatorname{Minimum}(<0.03)$ & $\begin{array}{l}\text { ation } \\
\text { period }\end{array}$ \\
\hline 3 & 1,4 and 6 & $\begin{array}{l}1,3,4,5,6,7,8,10,17 \\
\text { and } 19\end{array}$ & $\begin{array}{l}48.20,8.15,1.39,50 . \\
37,10.15,1.4,52.27, \\
11.15 \text { and } 1.49\end{array}$ & $\begin{array}{l}0.02,0.01,0.01,0.01,0.01,0 \\
.01,0.01,0.02,0.01 \text { and } 0.01\end{array}$ & $\begin{array}{l}1995 \\
2003 \\
2013 \\
\end{array}$ \\
\hline
\end{tabular}

The examinations of different sub basins on their percentage contribution to the changes of the stream flow and simulated sediment were evaluated to get the prominent sub basin contributor of the catchment. The highest annual surface runoff was attributed by sub basin, 5 and 6, respectively the contribution of ground water flow is maximum for sub basin, 5 and 6 respectively for 1995, 2003 and 2013 and minimum from sub basin, 16, 17, 18 and 19 for the period of 1995, 2003 and 2013 respectively. In terms of sediment yield, sub basins 1,4,6,15,16,18 and 19 contributes a maximum load whereas sub basins 1,3,4,5,6,7,8,10,17 and 19contributes a minimum sediment load for the study periods. 5) For 1995, 2003 and 2013 and the minimum from sub basin 7, 10 and 16, for 1995, 2003 and 2013 respectively. 


\section{Conclusions and Recommendations \\ 4.1 Conclusions}

The impact of the land cover change on stream flow was analyzed statistically using the hydrological model, SWAT. To do this analysis, first land use and land cover change during the past 18 years (1995 - 2013) was analyzed; then SWAT model were tested for its performance at the Muga watershed in order to examining the hydrological response of the watershed to changes in land use and land cover. The ArcGIS uses for the processing of DEM, land use and land cover, soil data layers and displaying model results. From the land use and land cover change analysis, it can be concluded that the land use and land cover of the Muga watershed for the period of 1995 to 2013 showed significantly changed. Cultivated land was drastically changed from $21 \%$ in 1995 to $55 \%$ in 2003 to $72 \%$ in 2013 the expenses of the other classes. The sensitivity analysis using SWAT model has pointed out ten most important parameters that control the stream flow of the studied watershed. On the other hand, model calibration and validation have showed that the SWAT model simulated the flow adequate satisfactorily.

Performance of the model for both the calibration and validation watershed were found to be reasonably good with Nash-Sutcliffe coefficients (ENS) values of 0.86 and 0.89 and coefficient of determination $\left(\mathrm{R}^{2}\right)$ values of 0.88 and 0.90 for the calibration and validation respectively. Following calibration and validation of the model, impacts of the land use and land cover change on stream flow was carried out. Land use and land cover changes recognized to have major impacts on hydrological processes, such as runoff and groundwater flow. The result of model for all periods of land use and land cover (1995, 2003 and 2013) indicated that during the wet season, the mean monthly flow for 2013 land cover was increased by $17.75 \mathrm{~m}^{3} / \mathrm{s}$ relative to that of 1995 land cover period while the mean monthly flow decreased by $12.76 \mathrm{~m}^{3} / \mathrm{s}$ during the dry season. The surface runoff increased from $309.37 \mathrm{~mm}$ to $329.37 \mathrm{~mm}$, while the ground water decreased from $380.37 \mathrm{~mm}$ to $345.14 \mathrm{~mm}$ from the 1995 up to 2013 land cover data's respectively.

Generally, this paper emphasizes that SWAT is a very flexible for Land-hydrologic models have proven to be efficient tools to meet the increasing demand for quantitative information on water availability and quality especially in response to changes in land-use, land management or climate. SWAT model is a potential and powerful model once calibrated and validated effectively for wide range of applications. The development of GISbased interfaces, which provide a simple means of translating digital land use, topographic, and soil data into model inputs, has greatly facilitated the process of configuring SWAT for a given catchment. Furthermore, advancement of a new era in SWAT application for LUCC simulation with the highest possible accuracy as a result of the new facilities for SWAT auto-calibration and uncertainty analysis was presented. Simulation of hypothetical, real and future scenarios.

\subsection{Recommendations}

Generally from this specific study the following recommendations could improve similar research for future work: Further research activities should be consider using different hydrological models in the region for the sake of further investigation of the impact of land use-cover change on the hydrology of sub basin. There should be better land management programs or practices that encourage afforestation so that precipitation during the rainy season could easily infiltrate and recharge groundwater. There should be strong encouragement and support in rainwater afforestation, water and soil conservation practice in community level.

Land use-cover change problems awareness at all levels (community, local, regional and national levels) and appropriate response techniques. It is recommendable to have more hydro meteorological data measurement instruments in and around the sub basin that could provide adequate data with better quality. Better data gathering techniques and dissemination process should be foreseen so that local and regional authorities can be involved in integrated and coordinated manner.

\section{Reference}

Abebe, S. (2005) Land-Use and Land-Cover change in headstream of Abbay watershed, Blue Nile Basin, Ethiopia. Addis Ababa University.

Aggarwal, S. (2009). Response of Hydrological Processes to Land-Cover and Climate Changes in Kejie Watershed, Southwest China. Hydrological Processes, 23, 1179-1191. http://dx.doi.org/10.1002/hyp.7233.

Arnold, J.G., Srinivasan, R., Muttiah, R.S. and Williams, J.R. (1998). Large Hydrologic Modeling and Assessment Part I: Water Resources Association, 34, 73-89. http://dx.doi.org/10.1111/j.1752-1688.1998.tb05961.x

Eiumonh A, Canisius FXJ, Baimoung S, Kesawatptiak p, Noomhorm A and shrestha RP. (1997). NOAA/AVHRR data for detecting land use change and its impact :A case of Mum Macro-watershed of North-Eastern region, Thailand.Pages234-244,In:Tangtham,N.,Thammincha,S. and Pungchit, 1.(Editors)proceedings of FORTROP 96 International conference :Tropical Forestry in the 21st century,2528 November 1996,Bangkok, Thailand

Gassman, P.W., Reyes, M.R., Green, C.H. and Arnold, J.G. (2007). The Soil and Water Assessment Tool: Historical Development, Applications and Future Research Directions. Transactions of the American Society 
of Agricultural and Biological Engineers, 50, 1211-1250. http://dx.doi.org/10.13031/2013.23637.

Green WH, Ampt G. (1911). Studies on soil physics, 1. The flow of air and water through soils. The Journal of the Agricultural Science 4: 1-24

Kulkarni AT, Bodke SS, Rao EP and Eldho TI. (2014). Hydrologic impact on change in land use / land cover in an urbanizing catchment of Mumbai: a case study. Published online Taylor and Francis: ISH Journal of Hydraulic Engineering Volume 20, Issue 3, 2014. pp 314-323.

Lambin, EF. (2001). the Causes of Land-Use and Land Cover Change: Global Environmental Change. Netherlands.

Lucas LFJ and Molenaar M. (1990). Terrain objects, their dynamics and their monitoring by the integration of GIS and remote sensing. IEEE Transactions on Geoscience and Remote Sensing, 33 (3).

Millennium Ecosystem Assessment (2005). In Millennium Ecosystem Assessment, Ecosystems and Human Well Being: General Synthesis, Millennium Ecosystem Assessment Series

Miller, S.N., Kepner, W.G., Mehaffey, M.H., Hernandez, H., Miller, R.C.,Goodrich, D.C., Devonald, K.K.,Heggem, D.T., Miller, W.P., (2002). Inte-grating landscape assessment and hydrologic modeling for land cover change analysis. Journal of the American Water Resources Association 38(4), 915e929

Nie, W., Yuan, Y., Kepner, W., Nash, M. S., Jackson, M and Erickson, C. Assessing impacts of Land use changes on hydrology for Journal of Hydrology. 407(1):105-114 (2011).

Rao KS and Pant R. (2001). Land Use Dynamics and Landscape Change Pattern in a Typical Micro Watershed inthe Mid Elevation Zone of Central Himalaya, India, Agriculture, Ecosystems and Environment, 86: 113123.

Richards JF. (1990). Land transformation in the earth as transformed by human action. Cambridge University Press, New York.Pp163-178.

Tadele, K. (2007) Impact of Land use/cover change on stream flow: the case of Hare River Watershed, Ethiopia. Arba Minch Water Technology Institute, Arba Minch University.

Walsh, C., (2005). Stream Restoration in Urban Catchments through Redesigning Storm-Water Systems: Looking to the Catchment to Save the Stream. Journal of the North American Ethological Society, 24, 690-705. http://dx.doi.org/10.1899/04-020.1

Williams, J.R. and Berndt, H.D. (1977). Sediment Yield Prediction Based on Watershed Hydrology. Transactions of the American Society of Agricultural and Biological Engineers, 20, 1100-1104. http://dx.doi.org/10.13031/2013.35710 